\title{
EVALUATING THE SORPTION OF THE ANTIMICROBIAL DANOFLOXACION IN SOILS, CLAYS AND HUMIC ACIDS
}

\author{
LEANDRO ALVES PEREIRA ${ }^{1}$, SANDRA MARIA DAL BOSCO $^{2}$ \\ ${ }^{1}$ Instituto Federal Catarinense, BR 280, km 27, 89245-000, Araquari, SC, Brazil \\ ${ }^{2}$ Fareva Pharmaceutical, 13295-000, 620, Itupeva, SP, Brazil
}

DOI: https://doi.org/10.51193/IJAER.2021.7110

\begin{abstract}
Large-scale animal production has been responsible for the introduction of fluoroquinolones in the environment and the occurrence of adverse effects in non-target organisms. Under this scenario, this study evaluated the sorption of danofloxacin (DAN) in a Brazilian sandy (N1) and clay soil (S2) and in their isolated humic acids (HAs) and clays. The drug presented higher sorption on S2 with Freundlich coefficient $\mathrm{pH}$-dependent ranging from 85 to $676 \mu \mathrm{g}^{1-1 / \mathrm{n}}(\mathrm{mL})^{1 / \mathrm{n}}$ $\mathrm{g}^{-1}$ on soils. Distribution coefficients $(\mathrm{Kd})$ showed the order: humic acids > clays > soils for N1 and S2. The Kd of N1 HA (less humificated and richer in oxygenated groups) was higher than S2 $\mathrm{HA}$, but $\mathrm{S} 2$ clay (with higher content of oxides of $\mathrm{Fe}$ and $\mathrm{Al}$ ) sorbed more DAN than N1 clay. The DRX data pointed a sorption process restricted to the external surfaces of kaolinite. After the sorption of DAN, the FTIR of HAs presented a reduction of signals of $\mathrm{COO}^{-}, \mathrm{C}=\mathrm{O}$ and $\mathrm{OH}^{-}$ groups, suggesting the contribution of ionic interactions and hydrogen bonding for sorption. The cation exchange mechanism was supported by the dependence of the ionic strength and nature of the exchangeable cation for the sorption of DAN. Also, the FTIR of sorbed DAN on S2 clay indicated the contribution of $\mathrm{Fe}$ and $\mathrm{Al}$ oxides in additional interactions with the molecule.
\end{abstract}

Keywords: Brazilian soils, clays, danofloxacin, humic acids, sorption

\section{INTRODUCTION}

Dispersion of veterinary antimicrobials is a matter of global concern, as they lead to contamination of soils, sediments and water bodies, the bioaccumulation and adverse effects in non-target organisms, the appearance of resistant bacteria and genes and the transfer of pharmaceuticals inter species through the food web, as previously ascertained (Blanco et al., 2017; Carvalho and Santos, 2016; Kuppusamy et al., 2018; Pan and Chu, 2017). 
International Journal of Agriculture and Environmental Research

ISSN: 2455-6939

Volume: 07, Issue: 01 "January-February 2021"

Antiparasitics, antimicrobials, hormones, antifungals, anti-inflammatory, among others, are commonly employed in food producing animals. Of these, the antimicrobials are the pharmaceuticals most widely used in the livestock industry (Baynes et al., 2016), including the animoglycosides, $\beta$-lactams, ionophores, peptides, cephalosporines, fluoroquinolones (FQs), lincosamides, macrolides, sulphonamides, tetracyclines and trimethoprim (Kuppusamy et al., 2018).

The widespread use of FQs has resulted in their detection in different environmental matrices, with concentrations of $\mu \mathrm{g} \mathrm{L}^{-1}$ in wastewater, $\mathrm{ng} \mathrm{L}^{-1}$ to $\mu \mathrm{g} \mathrm{L}^{-1}$ in freshwater, $\mu \mathrm{g} \mathrm{kg}^{-1}$ in soils and $\mu \mathrm{g} \mathrm{kg}^{-1}$ to $\mathrm{g} \mathrm{kg}^{-1}$ in animal manure (Riaz et al., 2018). Regarding the uncertainties about the effects of the veterinary drugs (VDs) on environment and human health, the World Health Organization, the World Organization for Animal Health and the FDA classified FQs and other antimicrobials as critically important (FAI, 2019).

FQs are a synthetic antimicrobial family derived from second generation of quinolones. They contain a fluorine atom in position 6 and one piperazinyl group at position 7, which are responsible for the antimicrobial activity and lower toxicity than first generation drugs (Doorslaer et al., 2014).

Danofloxacin (DAN) is an FQ for husbandry use and marketed in Brazil by Zoetis with the generic name Advocin ${ }^{\circledR}$ (SINDAN, 2019). DAN is active against gram-negative bacteria, grampositive and mycoplasma due to its capacity to inhibit DNA gyrase. The drug exhibits excellent activity against respiratory pathogens of cattle, pigs and poultry, demonstrating therapeutic efficacy in the treatment of natural and induced respiratory infections in these species (Chen et al., 1997; Pfizer, 2018).

FQs are molecules of amphoteric nature and can exist in different speciation forms, according to its pka values. Thus, the sorption of these pharmaceuticals is $\mathrm{pH}$-dependent and influenced by ionic strength of the media, by the soil cation exchange capacity and texture (Doorslaer et al., 2014). In addition, they display a low leaching potential and a high affinity for sludge, soils and sediments, due to the formation of ion-ion or ion-dipole interactions with soils (Doorslaer et al., 2014, Riaz et al., 2018).

Computational and spectroscopic investigations, employed to elucidate the sorption of fluoroquinolones in soils, have indicated that these drugs are able to substitute or to complex with cations associated with negative sorption sites ( $\mathrm{Gu}$ et al., 2015; Nowara et al., 1997). Thus, the soil organic phase acts as sorbent for these VDs, as the presence of $\mathrm{COOH} / \mathrm{OH}$ moieties makes complexation possible, mediated by cations, with polar groups of the molecules (Mackay and Vasudevan, 2012). 
International Journal of Agriculture and Environmental Research

ISSN: 2455-6939

Volume: 07, Issue: 01 "January-February 2021"

Previous studies have investigated the sorption of FQs on humic acids (HAs) and clay minerals, pointing these materials to be suitable for the remediation of environmental matrices. In addition, the use of the soil mineral fraction as an adsorbent for pollutants is feasible because of their low cost, high surface area, high porosity and abundance (Rivagli et al., 2014; Zhao et al., 2019).

FQs have similar structures and their adsorption behavior is expected to show a general trend for different drugs. However, the groups within a peculiar molecule and the matrix composition may influence the interactions of these VDs and soils or their organic and inorganic phases.

Our literature review indicates that there have been few studies dealing with sorption of DAN in soils so far. However, these studies did not ascertain the factors of influence on the retention of this drug nor how the interaction with soils and their organic and inorganic phases occurs. Based on these facts, the aim of this study is to evaluate the sorption coefficients of DAN in two Brazilian subtropical soils and their clay and HA fractions. In addition, to investigate the factors responsible for the drug retention.

\section{MATERIAL AND METHODS}

\subsection{Reagents, solvents and standard solutions}

DAN 99.8\% (CAS registry No. 112398-08-0) was purchased from Fluka (EUA) and their stock solution $\left(1000 \mu \mathrm{g} \mathrm{mL}^{-1}\right)$ was prepared with formic acid and methanol of chromatographic grade purchased from Merck (Germany). Formic acid was purchased from Synth (Brazil). Ethylenediaminetetraacetic acid (EDTA) was purchased from Aldrich (EUA). Aqueous solutions were prepared with ultrapure water from Milli-Q system (Millipore, EUA). Boric acid (SigmaAldrich, EUA), phosphoric acid (Synth, Brazil), acetic acid (Synth, Brazil), hydrochloric acid (Synth, Brazil) and sodium azide (Sigma-Aldrich, EUA) were used to prepare Britton-Robinson Buffer (BR). Sodium pyrophosphate, 30\% hydrogen peroxide, sodium hexametaphosphate and sodium carbonate were purchased from Synth (Brazil).

\subsection{Sampling sites, sample collection and soil characterization}

To investigate the sorption of DAN, we selected two Brazilian subtropical soils with distinct texture, organic matter and cation exchange capacity (CEC) content. The soils were collected in different regions of São Paulo State, Brazil. The sampling site, the soils characterization, and the sampling procedure of sandy soil N1 and clay soil S2 are described in Dionisio and Rath (2016). According to the U.S. Soil Taxonomy, N1 and S2 correspond to entisol quartzipsamment and oxisol, respectively.

\subsection{Extraction of humic acid and clay}


International Journal of Agriculture and Environmental Research

ISSN: 2455-6939

Volume: 07, Issue: 01 "January-February 2021"

The HAs were extracted from soils $\mathrm{N} 1$ and $\mathrm{S} 2$ adopting the protocol proposed by the International Humic Substance Society. A molecular weight cutoff of 1000 MW (Spectra/Por ${ }^{\circledR} 1$, USA) was employed for HA dialysis. The purified HAs were stored at ambient temperature until use.

The oxidation of soil organic matter was performed according to the procedure of the Agronomic Institute of Campinas (Camargo, 1986). Then, the steps of dispersion and separation of mineral factions were executed as proposed by International Soil Reference and Information Centre (ISRIC, 2002).

Initially, $200 \mathrm{~mL}$ of $0.1 \mathrm{~mol} \mathrm{~L}^{-1}$ sodium pyrophosphate and $50 \mathrm{~mL}$ of hydrogen peroxide $30 \%$ were added to samples of $10 \mathrm{~g}$ of soil. The mixture was kept at rest overnight and heated at $40{ }^{\circ} \mathrm{C}$ for 8 hours the following day. Then, the temperature was increased to $80{ }^{\circ} \mathrm{C}$ until next dryness. The samples were washed and centrifuged until measured conductivity was below $0.4 \mathrm{mS} / \mathrm{cm}$. Then, $20 \mathrm{~g}$ of treated soils were transferred to a $1 \mathrm{~L}$ polythene bottle receiving $20 \mathrm{~mL}$ of dispersing agent (sodium hexametaphosphate $4 \%+$ sodium carbonate $1 \%$ ). The volume was completed to $400 \mathrm{~mL}$ and the flask was stirred overnight. The suspension was passed through a $50 \mu \mathrm{m}$ sieve, washed and transferred to a graduated cylinder. The volume was completed to $1 \mathrm{~L}$ and the recipe was kept at rest for 5.5 hours. The clay fraction was collected according to Stockes' Law. The suctioned liquid was evaporated and dried overnight at $105^{\circ} \mathrm{C}$.

\subsection{Characterization of humic acid and clay fractions}

Fourier transform infrared spectroscopy (FTIR): The FTIR spectra were obtained on an Agilent Cary 630 FTIR (USA) with the $\mathrm{KBr}$ technique at $400-4000 \mathrm{~cm}^{-1}$ with resolution of $4 \mathrm{~cm}^{-1}$ and sixty-four scans.

X-ray diffraction (XRD): XRD spectra of samples were produced using the powder method on a Shimadzu XRD7000 diffractometer (Japan) using $\mathrm{Cu} \mathrm{K \alpha}$ irradiation at $40 \mathrm{kV} / 30 \mathrm{~mA}$ and 3 to $65^{\circ} 2 \Theta$. The scanning rate was $2^{\circ} / \mathrm{min}$ with step size of $0.02^{\circ}$. Occurrence of the possible minerals was identified by comparing the intensity of the signals, the calculated d-spacing values from the Bragg's Law and the data from the American Mineralogist Crystal Structure Database. The software Match! Phase Identification from Powder Diffraction (version 1.11k) was employed to confirm the results.

Elemental composition: The HAs were analyzed on a Perkin Elmer 2400 CHNS (USA) elemental analyzer. Relative quantities of $\mathrm{C}, \mathrm{H}$ and $\mathrm{N}$ were measured directly with the analyzer, and the data were recalculated on an ash-free basis. The oxygen contribution was estimated as the difference between the summed $\mathrm{C}, \mathrm{H}$ and $\mathrm{N}$ concentrations and $100 \%$. 
International Journal of Agriculture and Environmental Research

ISSN: 2455-6939

Volume: 07, Issue: 01 "January-February 2021"

\subsection{Studies conditions and sample processing}

All assays were performed in falcon tubes protected from light at $25{ }^{\circ} \mathrm{C}$ employing a horizontal shaker (Marconi, Brazil). In all experiments the soil/solution mixtures were pre-equilibrated for 24 hours before the addition of DAN. For the quantification of DAN, the soil/solution/drug mixtures were centrifuged at $4186 \mathrm{~g}$ for 15 minutes and an aliquot of $2.00 \mathrm{~mL}$ was collected and transferred to another flask to receive approximately $10 \mathrm{mg}$ of EDTA followed by sonication for 10 minutes. Finally, the solutions were filtered $(0.22 \mu \mathrm{m})$ and free DAN was determined by the chromatographic method 2.6.

\subsection{HPLC analysis}

Quantification of DAN was performed with an Agilent 1200 liquid chromatography (Agilent Tech., EUA) equipped with a fluorescence detector, an X Bridge ${ }^{\mathrm{TM}}$ Shield RP $18(4.6 \times 200 \mathrm{~mm}$, $5 \mu \mathrm{m})$ column and an X Bridge ${ }^{\mathrm{TM}}$ Shield RP $18(4.6 \times 20 \mathrm{~mm}, 5 \mu \mathrm{m})$ guard column. The mobile phase used a mixture of methanol and formic acid $0.1 \%(29: 71, \mathrm{v} / \mathrm{v})$. The flow rate was $1.0 \mathrm{~mL}$ $\min ^{-1}$ and the injection volume was $10 \mu \mathrm{L}$. The column temperature was $30^{\circ} \mathrm{C}$ and the detection was performed using the wavelengths of excitation and emission of 245 and $280 \mathrm{~nm}$, respectively.

\subsection{Preliminary studies}

The preliminary studies comprised of: a) the evaluation of stability of DAN in solution, b) the optimization of the optimum soil/solution ratio and, c) the determination of sorption equilibration time.

The stability test was performed in five solutions of $50.0 \mathrm{mg} \mathrm{L}^{-1} \mathrm{DAN}$ in $40 \mathrm{mmol} \mathrm{L}^{-1} \mathrm{BR}$ buffer at $\mathrm{pH}$ 5.0, 7.5 and 10 at $25^{\circ} \mathrm{C}$. The samples were kept in falcon tubes protected from light at 25 ${ }^{\circ} \mathrm{C}$ and sampled for 6 days following the step 2.6.

For selection of soil/solution ratio $1 \mathrm{mg}$ of DAN was added to triplicate soil mixtures of $0.5,1.0$, 2.0 and $5.0 \mathrm{~g}$ (previously equilibrated for 24 hours with $40 \mathrm{~mL}$ of $40 \mathrm{mmol} \mathrm{L}^{-1} \mathrm{BR}$ buffer at $\mathrm{pH}$ 5.0) and kept under agitation for 24 hours before the chromatographic quantification.

To evaluate the sorption kinetics, free DAN (at initial concentration of $25 \mathrm{mg} \mathrm{L}^{-1}$ ) was determined in soil/40 $\mathrm{mmol} \mathrm{L}^{-1} \mathrm{BR}$ buffer mixtures $(1: 80, \mathrm{w} / \mathrm{v} ; \mathrm{pH} 5.0)$ after the equilibration period of 96 hours $(n=2)$. Kinetic data were fitted to pseudo-first-order, pseudo-second-order (PSO) and Elovich models.

\subsection{Sorption on soils, humic acids and clays}


To determine the distribution coefficient (Kd) on soils, clays and Has, the DAN, initially added at $2.5 \mathrm{mg} \mathrm{g}^{-1}$, was quantified after the equilibrium of 24 hours of mixtures 1:80 (w/v, n = 3) prepared in $0.01 \mathrm{~mol} \mathrm{~L}^{-1} \mathrm{CaCl}_{2}$. The assays were performed in triplicate and the samples were dried at $65^{\circ} \mathrm{C}$ before the XRD analysis.

\subsection{Sorption and desorption isotherms}

Sorption and desorption experiments were performed using the batch equilibrium method in agreement with the parallel method described in the OECD 106 Guide (OECD, 2000). Initially, DAN $\left(0.5-2.5 \mathrm{mg} \mathrm{g}^{-1}\right)$ was added to soil mixtures $1: 80(\mathrm{w} / \mathrm{v}, \mathrm{n}=3)$ of $40 \mathrm{mmol} \mathrm{L}^{-1}$ BR buffer (pH 5.0, 7.5 and 10) and $0.01 \mathrm{~mol} \mathrm{~L}^{-1} \mathrm{CaCl}_{2}$ following agitation for 24 hours. Then, the aqueous phase was processed, analyzed and replaced by a new one. Desorbed DAN was determined in solution after $72 \mathrm{~h}$ of equilibration.

\subsection{Influence of ionic strength and cations on sorption of danofloxacin}

The influence of ionic strength on sorption was evaluated measuring the concentration of free DAN in soil mixtures, 1:80 (w/v) prepared in 0.005, 0.01, 0.05 and $0.1 \mathrm{~mol} \mathrm{~L}^{-1} \mathrm{CaCl}_{2}$, after the equilibration period of 24 hours. To investigate the sorption in the presence of different cations, the initial aqueous phase was replaced by magnesium $\left(0.01 \mathrm{~mol} \mathrm{~L}^{-1}\right)$, potassium $\left(0.02 \mathrm{~mol} \mathrm{~L}^{-1}\right)$ and sodium chloride $\left(0.02 \mathrm{~mol} \mathrm{~L}^{-1}\right)$. All experiments were performed in triplicate.

\section{RESULTS AND DISCUSSION}

\subsection{Humic acid and clay characterization}

The mineral and organic phases of two Brazilian soils with distinct textural classes were isolated to investigate the sorption of DAN. The characterization of clays was performed by FTIR and XRD. The constitution of HAs was investigated by FTIR and elemental analysis.

The bands observed in the spectra of clays and HAs are shown in Fig. 1, and their possible assignments are presented in Table 1. 


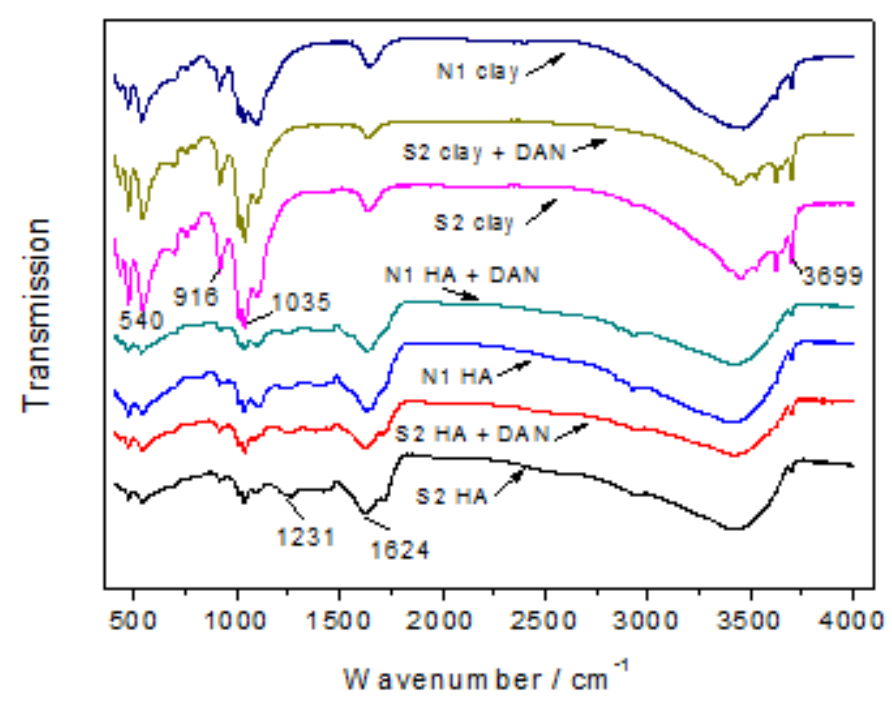

Fig. 1: Fourier Transform Infrared spectra of N1 and S2 clay/humic acid before and after sorption of danofloxacin.

\begin{tabular}{|c|c|c|c|}
\hline \multicolumn{2}{|r|}{ Clay } & \multicolumn{2}{|r|}{ Humic acid } \\
\hline $\begin{array}{l}\text { Band } \\
\left(\mathrm{cm}^{-1}\right)\end{array}$ & Assignm ents & $\begin{array}{l}\text { Band } \\
\left(\mathrm{cm}^{-1}\right)\end{array}$ & Assignments \\
\hline 3699 & Al--O-H stretching & 3699 & $\mathrm{OH}$ axial deform ation of kaolinite \\
\hline 3622 & $\begin{array}{l}\text { Al--O-H stretching } \\
\text { (inter-octahedral) }\end{array}$ & 3404 & $\begin{array}{l}\text { OH deformation of phenolic group; aliphatic } \\
\mathrm{OH} ; \mathrm{H}_{2} \mathrm{O} ; \text { amine }\end{array}$ \\
\hline 3449 & H-O-H stretching & 2920 & $\begin{array}{l}\text { C-H asymm etric axial deformation of } \\
\text { methyl and m ethylene }\end{array}$ \\
\hline 1035 & $\mathrm{Si}-\mathrm{O}-\mathrm{Si} ; \mathrm{Si}-\mathrm{O}$ stretching & 1624 & $\begin{array}{l}\text { Asymm etric axial deformation of } \mathrm{COO}^{-} \\
\text {covalently linked to m etal; amide; ketone or } \\
\text { quinone }\end{array}$ \\
\hline 916 & Al--O-H angular deform ation & 1231 & $\begin{array}{l}\mathrm{C}-\mathrm{OH} \text { axial deformation of carbonic and } \\
\text { phenolic groups }\end{array}$ \\
\hline 797 & O-H translacional deform ation & 1037 & Si-O axial deform ation of kaolinite; \\
\hline 696 & $\mathrm{Si}-\mathrm{O}$ angular deform ation & 473 & $\mathrm{Si}-\mathrm{O}$ deformation of kaolinite \\
\hline 540 & $\mathrm{Si}-\mathrm{O}-\mathrm{Al}$ angular deform ation & & \\
\hline 473 & $\mathrm{Si}-\mathrm{O} ; \mathrm{Si}-\mathrm{O}-\mathrm{Fe}$ stretching & & \\
\hline
\end{tabular}

Table 1: Infrared bands of clays/humic acids and their possible assignments. ${ }^{(1)}$

(1) References: Bergaya, 2006; Madejová, 2003; Nakamoto, 2009; Russel and Wilson, 1987; Stevenson, 1994.

The spectra of clays are similar, showing the same minerals in the samples and the presence of characteristics bands ranging in intensity. The appearance of signals around 3699, 3622, 3449, 1035, 916, 797, 696, 540 and $473 \mathrm{~cm}^{-1}$ indicates kaolinite in clays, confirmed by the presence of 
a broad band at $3449 \mathrm{~cm}^{-1}$ that is attributed to the presence of water of hydration in these minerals. Vibrations observed at $916 \mathrm{~cm}^{-1}$ indicate the presence of hematite. Bands observed at $473,540,1035,3622$ and $3699 \mathrm{~cm}^{-1}$, referent to the Al-OH, Si-O-Al and Si-O-Fe vibrations, are more intense for $\mathrm{S} 2$ clay, pointing that this material is richer in oxides of iron and aluminum.

The infrared spectra profile of HAs was also similar, showing characteristics peaks and the presence of some residual kaolinite and gibbsite, common impurities of the extraction process (Russel, 1987). In $2920 \mathrm{~cm}^{-1}$ the $\mathrm{N} 1 \mathrm{AH}$ presented a slightly more pronounced peak, indicating a more aliphatic composition, rich in substances less humificated such as carbohydrates (Stevenson, 1994). On the other hand, the more humificated S2 HA displayed a greater amount of aromatic structures, which is pointed by the more intense signal in $1231 \mathrm{~cm}^{-1}$, referent to the $\mathrm{C}-\mathrm{OH}$ axial deformation of carbonic and phenolic groups.

XRD technique was employed to investigate the mineralogical composition of the materials as the species present a diffractometric pattern, characteristic for each crystalline substance and equivalent to a digital print. Fig. 2 presents the spectra of isolated clays. According to the calculated d values of diffraction peaks it was possible to identify the presence of kaolinite and hematite on booth clays, corroborating with the information pointed through the FTIR results.

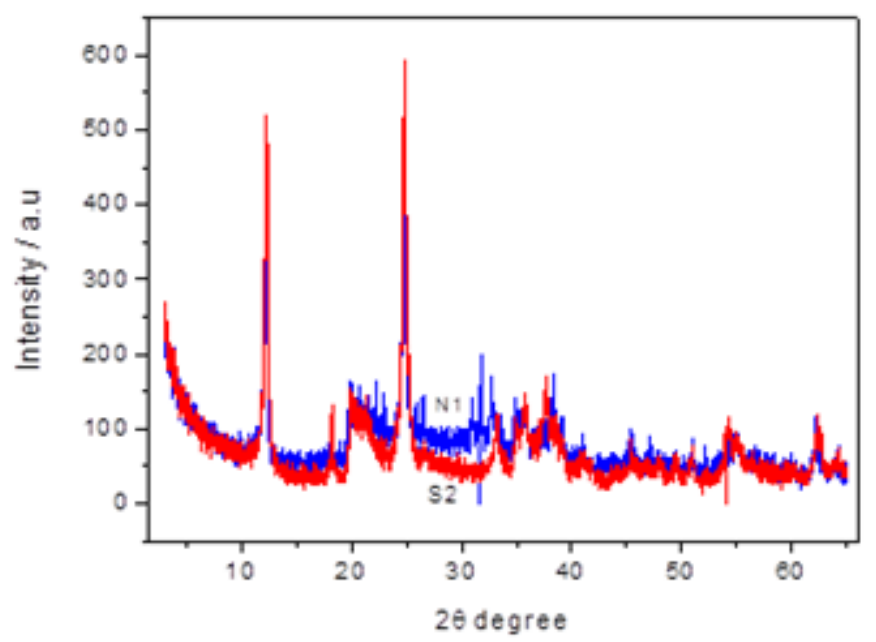

Fig. 2: $\mathrm{X}$-ray diffraction spectra of $\mathrm{N} 1$ and $\mathrm{S} 2$ clays.

The elemental analysis indicated respectively $32.96 ; 4.07 ; 2.83$ and $60.14 \%$ of carbon, hydrogen, nitrogen and oxygen for N1 HA. For S2 HA the results were 34.54; 3.79; 2.34 and 59.33\%, respectively. The $\mathrm{C} / \mathrm{H}$ ratio was calculated once this parameter is associated with the aromaticity and humification degree of HAs (Stevenson, 1994). Therefore, the lower C/H ratio of N1 HA (8.09) confirmed a greater number of aliphatic groups and a less humificated material in 
International Journal of Agriculture and Environmental Research

ISSN: 2455-6939

Volume: 07, Issue: 01 "January-February 2021"

comparison with S2 HA $(\mathrm{C} / \mathrm{H}=10.18)$, corroborating with the FTIR information. Also, the O/C ratio of the HAs indicated a higher presence of oxygenated groups in $\mathrm{N} 1 \mathrm{HA}(\mathrm{O} / \mathrm{C}=1,82)$ in comparison with S2 HA $(\mathrm{O} / \mathrm{C}=1,71)$, which is pointed by the more intense band in $1624 \mathrm{~cm}^{-1}$, referent to the asymmetric axial deformation of $\mathrm{COO}^{-}$and $\mathrm{C}=\mathrm{O}$ groups (Fig. 1).

\subsection{Experimental conditions and preliminary studies}

Adsorption of DAN on test vessel was negligible in preliminary studies and all assays were performed in falcon tubes. The quantification of sorbed DAN was carried out through the difference between its initial and final amount present in solution. The addition of EDTA, followed by a sonication step prior to the chromatographic analysis, was necessary to inhibit the formation of drug-cation-soluble organic matter complexes in solution. Peruchi et al. (2015) demonstrated that these high molar mass complexes have less affinity for the octadecyl stationary phase and elute at the beginning of the chromatogram, causing a decrease on norfloxacin signal and a strong matrix effect. Thus, the sample preparation step 2.5 was included previously to the drug chromatographic determination in all experiments.

Due to the amphoteric behavior of DAN, sorption coefficients of the VD were also evaluated in distinct $\mathrm{pH}$ values. The $\mathrm{pHs}$ 5.0, 7.5 and 10 were selected because the molecule was $94 \%, 89 \%$ and $96 \%$ cationic, zwitterionic and anionic, respectively (pka 1 : 6.22 and $\mathrm{pka}_{2}: 9.43$ ).

As the OECD 106 guidelines do not establish a protocol of how the $\mathrm{pH}$ can be controlled, several buffers like chloroacetate, acetate, MES, PIPES and MOPS were reported for sorption studies of ionizable VDs in soils (Carrasquillo et al., 2008; Figueroa-Diva et al., 2010; Figueroa and Mackay, 2005; Gu and Karthikeyan, 2005; Vasudevan et al., 2009). Sorption studies were initially performed in $0.01 \mathrm{~mol} \mathrm{~L}^{-1} \mathrm{CaCl}_{2}$ with $\mathrm{pH}$ adjusted through the addition of $\mathrm{HCl}$ or $\mathrm{NaOH}$, which resulted in a significant change of the initial values at the end of the experiments. Therefore, the BR buffer was chosen for the continuation of the studies, as it enables the preparation of buffers over a wide $\mathrm{pH}$ range $(2<\mathrm{pH}>12)$ with the same reagents. Thus, it was possible to evaluate the sorption of ionizable forms of DAN at different $\mathrm{pH}$ values without changing the chemical composition of the medium.

According to the stability test (data not shown), DAN was stable for six days in $40 \mathrm{mmol} \mathrm{L}^{-1} \mathrm{BR}$ buffer at three selected $\mathrm{pH}$ values, as no significant difference $(\mathrm{p}=0.05)$ was observed between the initial and final mean concentration of the drug in solution.

Evaluation of an appropriate soil-to-solution ratio was performed at 1:8, 1:20, 1:40 and 1:80 $(\mathrm{w} / \mathrm{v})$. The condition 1:80 was chosen for subsequent experiments since the sorption of DAN was above 50\%, which is in agreement with OECD 106 recommendations (OECD, 2000). 
The plots of sorbed DAN versus time (data not shown) indicated that the period of 1440 minutes (24 h) was sufficient to reach the apparent sorption equilibrium. Therefore, this time was adopted for sorption experiments. According to the data, a rapid sorption was observed during the first 480 minutes, followed by a slower sorption process. The experimental results were best fitted to the PSO model ( $\mathrm{r}>0.99$ ), suggesting a chemisorption process proportional to the solute concentration and to the number of sites not occupied in the sorbent (Ho and Mackay, 1998). According to this approach, the PSO rate constant $(k)$ indicated a faster sorption of DAN in S2 in

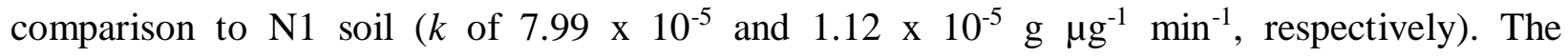
equilibrium sorption capacity $\left(\mathrm{q}_{\mathrm{e}}\right)$ pointed to a higher sorption on $\mathrm{S} 2$ in contrast with $\mathrm{N} 1$ ( $\mathrm{q}_{\mathrm{e}}$ of 1819 and $1111 \mu \mathrm{g} \mathrm{g}^{-1}$, respectively).

\subsection{Sorption on soils, humic acids and clays}

The Kd values of sorption of DAN in $0.01 \mathrm{~mol} \mathrm{~L}^{-1} \mathrm{CaCl}_{2}$ on soils, clays and HAs are indicated in Fig. 3. These studies were performed in the natural soil $\mathrm{pH}$ close to 5 , where the molecule was up to $90 \%$ in cationic form.

According to these data, the antimicrobial presented $\mathrm{Kd}$ from $111-3378 \mathrm{~mL} \mathrm{~g}^{-1}$ for $\mathrm{N} 1$ and 427 - $2381 \mathrm{~mL} \mathrm{~g}^{-1}$ for $\mathrm{S} 2$, showing the tendency: sorption on HA > clay > soil in both cases. Except for the HAs, the retention of DAN was higher for S2 clay and soil.

As expected, a superior Kd for DAN on soil S2 was confirmed, since its presents a clay texture, a higher cation exchange capacity (CEC), a higher organic matter content and, thus, a great amount of possible sorption sites in comparison with the sandy soil N1 (see physicochemical properties, Dionísio and Rath, 2016). Therefore, the behavior observed for DAN is consistent with previous studies that indicated a favored sorption of ciprofloxacin (CIP), norfloxacin (NOR) and enrofloxacin (ENR) on soil S2 to the detriment of N1 (Rath et al., 2019). 


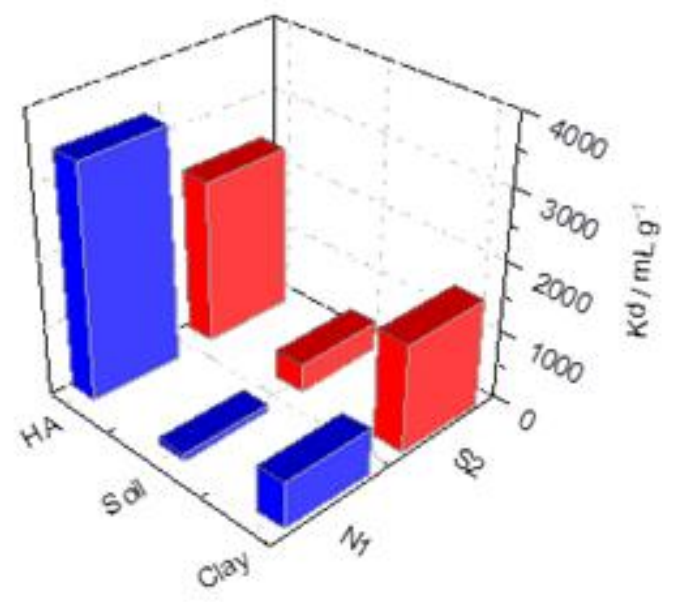

Fig. 3: Distribution coefficient (Kd) of danofloxacin on humic acids, soils and clays $(\mathrm{n}=3)$.

The results pointed in Fig. 3 indicate that the type of soil, the soil fraction and the constitution of the clays and HAs influenced the sorption of DAN. The sorption on HAs was about 2 to $9 \%$ higher in comparison with the clays and $15-68 \%$ greater in relation to the original soil. Also, the $\mathrm{Kd}$ of DAN on $\mathrm{N} 1 \mathrm{HA}$ is $42 \%$ greater in relation to $\mathrm{S} 2 \mathrm{HA}$.

So, our data corroborate with Martínez-Mejía et al. (2017) which observed a sorption of ENR onto the humic acid about 10 to 30 - fold higher than onto the soil from which they were extracted. Furthermore, Teixidó et al., (2014) also ascertained that the presence of humic acids increased the sorption magnitude of ENR and CIP on soils.

Due to their composition, the humic substances play an important role on the sorption of VDs, as they act as a sorbent for these substances. This soil organic phase is $\mathrm{pH}$ dependent and composed of carbon and hydrogen with large non-polar domains with $\mathrm{COOH} / \mathrm{OH}$ ligand groups. Thus, theoretically, they are able to link with FQs in acid media via: a) ionic interaction between the negatively charged moieties of the HA and the positively charged nitrogen at piperazinyl group of FQ; b) hydrogen bonding between the oxygens of carbonyl or carboxylic group of FQ and hydroxyl group of HA; c) cation bridging, mediated by positive ions, involving the oxygens of the carbonyl or carboxylic group of FQ molecule and hydroxyl groups of the HAs and; d) interaction of the ternary complex drug-ion-drug formed in solution and negatively charged moieties of the HAs (Cuprys et al., 2018).

As observed, FTIR spectra and $\mathrm{C} / \mathrm{H}$ ratio pointed that $\mathrm{N} 1 \mathrm{HA}$ is a less humificated material, possessing a greater number of aliphatic groups, a major content of low molecular weight humic substances and a higher content of oxygenated groups (like $\mathrm{COO}^{-}$and $\mathrm{C}=\mathrm{O}$ moieties), which act as possible sorption sites and enables a greater interaction with DAN species and, thus, an 
International Journal of Agriculture and Environmental Research

ISSN: 2455-6939

Volume: 07, Issue: 01 "January-February 2021"

increase on sorption of the VD in comparison with S2 HA. These results corroborate with Martínez-Mejía et al. (2017), which indicated a smaller Kd for ENR in more aromatic, condensed and recalcitrant HA structure.

According to Fig. 1 we observed a reduction on peak intensity of FTIR of HAs in the presence of DAN in $1624 \mathrm{~cm}^{-1}$ (asymmetric axial deformation of $\mathrm{COO}^{-}, \mathrm{C}=\mathrm{O}$ ) and $3000-3600 \mathrm{~cm}^{-1}(\mathrm{OH}$ deformation of phenolic group; aliphatic $\mathrm{OH} ; \mathrm{H}_{2} \mathrm{O}$ ), which according to Cuprys et al., (2018) may suggests: a) the formation of ionic interactions between carboxylic groups of HAs and $\mathrm{DAN}^{+}$and/or DAN ${ }^{+}-\mathrm{Ca}^{2+}$ moieties and; b) the formation of hydrogen bonding or cation bridging involving DAN species and $\mathrm{OH}$ groups located at HAs.

The hydration of kaolinite surface takes to the formation of Al-OH-Al, Al-OH and silanol ( $\mathrm{Si}$ $\mathrm{OH})$ groups with $\mathrm{pH}$-dependent ionization. Thus, even with point of zero charge close to $\mathrm{pH} 3$ and the dissociation of silanol group in $\mathrm{pH}<2$, these clays present an excess of negative charge in a wide range of soil $\mathrm{pH}$ (Melo and Alleoni, 2009), favoring the sorption of cationic DAN and resulting in higher Kd values in comparison with the natural soils, as verified in Fig. 3.

The XRD allowed us to investigate the sorption of DAN on clays. As expected, the sorption was restricted to the external surfaces of kaolinite, due to its nonexpanding property. Except by a reduction on signal intensity of kaolinite and hematite, the spectra of sorbed DAN on clays (data not shown) did not present a displacement of the initial signals, confirming no intercalation of VD molecules into the interlayers of the mineral, which is consistent with results presented for ENR (Wan et al., 2013).

The sorption on S2 clay was 2.4 times higher in comparison with N1 clay. As observed, the FTIR data (Fig. 1) indicated a higher content of hematite and oxides of iron and aluminum in S2 isolated clay and a reduction of signals referent to $\mathrm{Al}-\mathrm{OH}, \mathrm{Si}-\mathrm{O}-\mathrm{Al}$ and $\mathrm{Si}-\mathrm{O}-\mathrm{Fe}$ vibrations was observed after the sorption of DAN. Considering the highly reactive surface of iron and aluminum oxides and their capacity to sorb FQs, it is plausible to presume the contribution of these minerals in additional interactions with DAN, which could reduce the concentration of the free molecule in solution and increase the Kd on S2 soil and clay. This assumption is supported by the studies which demonstrated the formation of a surface monodentate complex between $\mathrm{Al}$ oxides and $\mathrm{COO}^{-}-\mathrm{CIP}$ group and keto oxygen and one oxygen from $\mathrm{COO}^{-}$, involved in the formation of a six-membered ring with Fe oxides (Gu and Karthikeyan, 2005).

\subsection{Sorption and desorption isotherms}

The sorption and desorption isotherms were constructed according to the soil/solution ratio and apparent equilibrium time established by the preliminary studies. The isotherms (Fig. 4) exhibited an adequate fit to the linear form of Freundlich equation, with $r>0.92$ in all cases. 

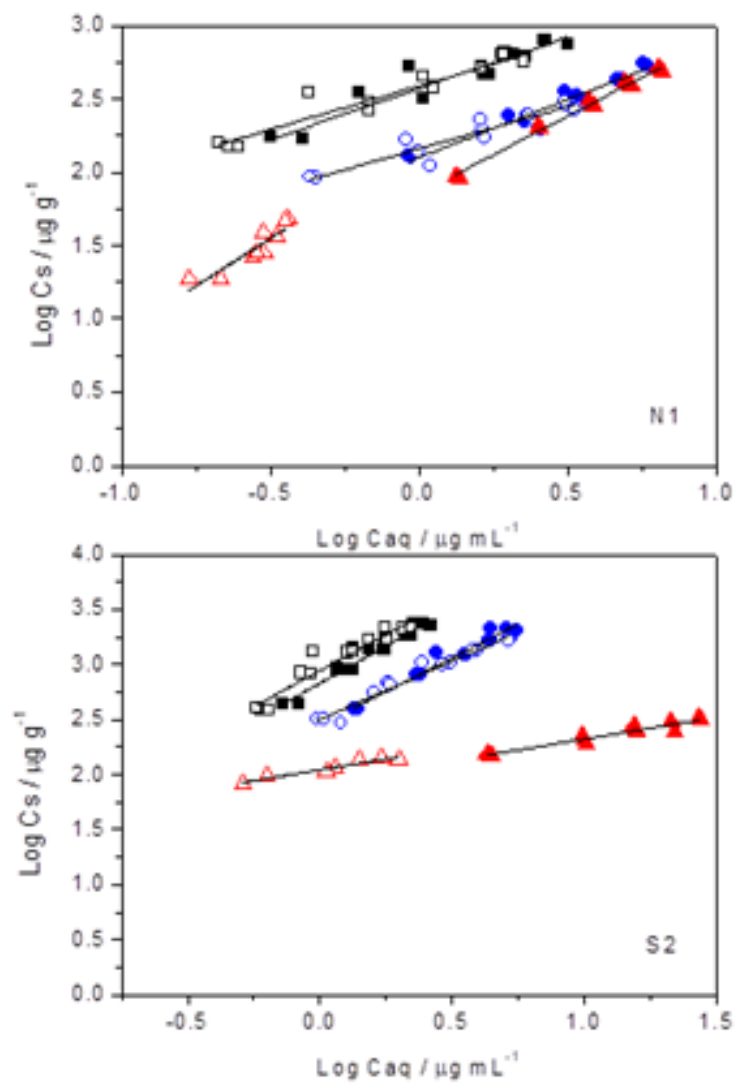

Fig. 4: Sorption (full symbols) and desorption (empty symbols) isotherms for danofloxacin on soils $\mathrm{N1}$ and $\mathrm{S} 2$ at pH 5 (square), 7.5 (circle) and 10 (triangle).

N1 and S2 presented Freundlich coefficient (KF) for sorption of 371, 126, 76 / 676, 280 and 85 $\mu \mathrm{g}^{1-1 / \mathrm{n}}(\mathrm{mL})^{1 / \mathrm{n}} \mathrm{g}^{-1}$, with regression constant $(1 / \mathrm{n})$ of $0.697,0.790,1.050 / 1.357,1.226$ and 0.395 for $\mathrm{pH} 5 ; 7.5$ and 10, respectively. These results confirm the higher retention capacity of the VD on S2 soil and indicated an increase of sorption capacity with the decrease of $\mathrm{pH}$ as observed for CIP (Jalil et al., 2015; Li et al., 2011; Vasudevan et al., 2009), ENR (Yan et al., 2012), levofloxacin (Liu et al., 2015) and NOR (Jie et al., 2009) in other soils and clay minerals.

The influence of $\mathrm{pH}$ on the sorption of DAN in $\mathrm{N} 1$ and $\mathrm{S} 2$ soils was recently ascertained in a work of our research group. Employing BR buffer, the Kd of the VD was assessed in pH 2 - 11, indicating maxima sorption of the cationic DAN in $\mathrm{pH} 5$ and a reduction of the Kdvalues in basic media (Rath et al., 2019). This finding agrees with the behavior observed for other FQs and suggests the cation exchange as the main sorption mechanism of DAN on evaluated soils and the contribution of secondary interactions, like cation bridging and hydrogen bonding, in basic media (Carrasquillo et al., 2008; Nowara et al., 1997). 
International Journal of Agriculture and Environmental Research

ISSN: 2455-6939

Volume: 07, Issue: 01 "January-February 2021"

The desorption step presented KF values of 387, 144, $131 / 882,317$ and $\left.110 \mu \mathrm{g}^{1-1 / \mathrm{n}}(\mathrm{mL})^{1 / \mathrm{n}} \mathrm{g}^{-1}\right)$, with $1 / \mathrm{n}$ of $0.594,0.573,1.305 / 1.309,1.053$ and 0.392 , for N1 and S2 in pH 5, 7.5 and 10, respectively, which indicated an unfavored desorption process, whereas desorption KF > sorption KF.

Our KFs of DAN are lower in comparison with the values of $2280-3000 \mu \mathrm{g}^{1-1 / \mathrm{n}}(\mathrm{mL})^{1 / \mathrm{n}} \mathrm{g}^{-1}$, presented by Pfizer (Pfizer 2018), for three soils varying in $\mathrm{pH}(5.6-7.6)$, organic carbon content $(0.59-3.1 \%)$ and with a considerably superior CEC in contrast with our soils (125 - 294 versus 19.3 and $66 \mathrm{meq} \mathrm{kg}^{-1}$ for $\mathrm{N} 1$ and S2, respectively). However, it is important to observe an increase of sorption of FQs in soils with higher CEC (Carrasquilo et al.,; 2008; Conckle et al., 2010; Vasudevan et al., 2009; Figueroa-Diva et al., 2010).

Sorption isotherms in $0.01 \mathrm{~mol} \mathrm{~L}^{-1} \mathrm{CaCl}_{2}$ (data not shown) presented $\mathrm{r}>0.95$, with $\mathrm{KF}$ of 217 and $630 \mu \mathrm{g}^{1-1 / \mathrm{n}}(\mathrm{mL})^{1 / n} \mathrm{~g}^{-1}$ and $1 / \mathrm{n}$ of 0.5306 and 0.5855 for N1 and S2 soils, respectively. It should be noted that all experiments were assessed under uncontrolled $\mathrm{pH}$ and, thus, the drug was predominantly positively charged due to natural soil $\mathrm{pH}$ close to 5 . The results do not indicate an interference of BR buffer in $\mathrm{pH}=5$ for soil S2 $\left(\mathrm{KF}=676 \mu \mathrm{g}^{1-1 / n}(\mathrm{~mL})^{1 / n} \mathrm{~g}^{-1}\right)$. However, the KF of $\mathrm{N} 1$ decreased to 371 (BR buffer, $\mathrm{pH}=5$ ) from $217 \mu \mathrm{g}^{1-1 / \mathrm{n}}(\mathrm{mL})^{1 / \mathrm{n}} \mathrm{g}^{-1}$ in calcium chloride. This behavior may be attributed to the appearance of a competition, between the protonated DAN and $\mathrm{Ca}^{2+}$ ions for the negative sorption sites, in cooperation with the lower CEC of this soil.

\subsection{Influence of ionic strength and cations on sorption of danofloxacin}

Some studies have demonstrated a significant influence of cationic species on the sorption of FQs in soils and clays (Chen et al, 2013; Jie et al, 2009; Li et al., 2019; Yan et al., 2012; Zhang et al., 2012). Thus, the ionic strength (I) of $\mathrm{CaCl}_{2}$ and the effect of other cations in solution was checked for DAN on N1 and S2.

As shown in Fig. 5, the increase of $\mathrm{Ca}^{2+}$ (from 0.005 to $0.1 \mathrm{~mol} \mathrm{~L}^{-1}$ ) resulted in a reduction of the $\mathrm{Kd}$ values of $\mathrm{N} 1$ and $\mathrm{S} 2$ from 151 to 35 and 638 to $123 \mathrm{~mL} \mathrm{~g}^{-1}$, respectively. These results agree with the behavior observed for other FQs, as some other studies have pointed an inhibition of sorption of these VDs, following the increase of I of cations in solution phase (Chen et al., 2013; Yan et al., 2012). 


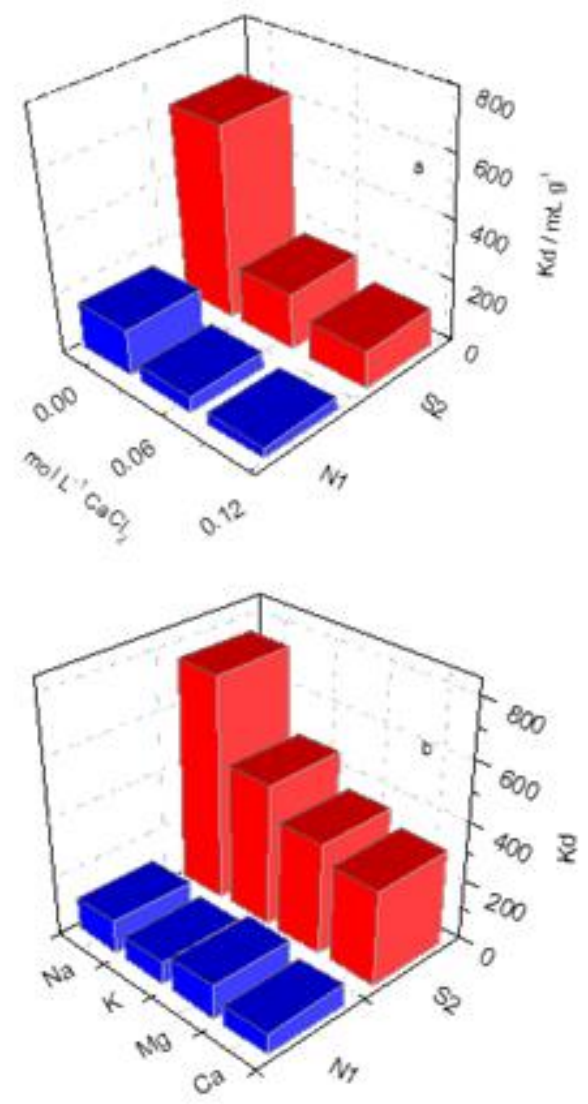

Fig. 5: Distribution coefficients (Kd) of danofloxacin on soils $N 1$ and $S 2$ in $0.005,0.05$ and $0.1 \mathrm{~mol} \mathrm{~L}^{-1} \mathrm{CaCl}_{2}$ solutions (a) and in the presence of mono and divalent cations (b).

On the other hand, some works have indicated an enhanced sorption of FQs, due to a higher binding affinity and the formation of a ternary VD--sorption sites complex with metal ions acting as mediators. $\mathrm{Cu}^{2+}$ and $\mathrm{Zn}^{2+}$ lead to an increase of sorbed ENR (Grauer-Bacart et al., 2015) and CIP presented enhanced sorption following the order: $\mathrm{Cu}^{2+}>\mathrm{Pb}^{2+}>\mathrm{Cd}^{2+}>\mathrm{Ca}^{2+}$ (Tan et al., 2014).

According to the Fig 5, soil S2 was the most affected by the nature of the exchangeable cation, presenting $\mathrm{Kd}$ values following the order: $\mathrm{Na}^{+}>\mathrm{K}^{+}>\mathrm{Mg}^{2+}>\mathrm{Ca}^{2+}$. For $\mathrm{N} 1$, the $\mathrm{Kd}$ values decreased in the sequence: $\mathrm{Na}^{+}>\mathrm{Mg}^{2+}>\mathrm{K}^{+} \approx \mathrm{Ca}^{2+}$. Also, the replacement of divalent cation $\mathrm{Ca}^{2+}$ for monovalent ion $\mathrm{Na}^{+}$in solution increased the $\mathrm{Kd}$ of $\mathrm{S} 2$ in $135 \%$.

These results, especially for S2, indicate that divalent cations competed with DAN for sorption sites located at humic substances and external surfaces of kaolinite. In opposition, monovalent cations facilitate the sorption rather than compete with it. 
Nevertheless, the different effect of cations in solution observed in N1 was ever reported for NOR in distinct soils. Kong et al. (2014) pointed that the enhancement or reduction on sorption efficiency depends not only the metal ion type in solution, but also by the soil properties, such as their CEC.

\section{CONCLUSIONS}

The studies performed in this work evaluated the sorption of the antimicrobial DAN in two Brazilian sandy and clay soils. The experiments indicated that the sorption of this VD was influenced by several factors such as the textural class of soils, their physicochemical properties, by the $\mathrm{pH}$, the I and nature of the exchangeable cation in solution.

Isolated clays and HAs demonstrated to play an important role for the sorption of DAN and retained more drug in comparison with the natural soils, while the HAs was most effective for molecule immobilization.

The results are consistent with previous studies performed with other FQs and indicate the contribution of ionic interactions, like cation exchange and cation bridging, hydrogen bonding and the participation of $\mathrm{Al}$ and $\mathrm{Fe}$ oxides for the retention of DAN on evaluated soils, HAs and clays.

The degree of humification of HAs and the constitution of clays showed to influence the retention of DAN and thus, these components of soils can affect the drug bioavailability in the environment.

\section{ACKNOWLEDGMENTS}

This research was supported by Fundação de Amparo à Pesquisa do Estado de São Paulo (FAPESP 10/06488-7, 13/09543-7, and 14/16995-4). The authors would like to thank the Agronomic Institute of Campinas for soil characterization, and EMBRAPA for soil sample supply and granulometric analysis. Also, our thanks to the professor Susanne Rath and the State University of Campinas that made this work possible.

\section{REFERENCES}

Ali-Mohamed, A.Y and A.H. Jaffar. 2000. Estimation of atmospheric inorganic water-soluble aerosols in the western region of Bahrain by ion chromatography. Chemosphere., 2: 8594.

Biswas, K.F., B.M Ghauri and L. Husain. 2008. Gaseous and aerosol pollutants during fog and clear episodes in South Asian urban atmosphere. Atm. Env., 42:7775-7785. 
International Journal of Agriculture and Environmental Research

ISSN: 2455-6939

Volume: 07, Issue: 01 "January-February 2021"

Central Department of Statistics and Information (CDSI), 2010. Saudi Arabia, www.cdsi.gov.sa/englishChemical Book (CB).

AMCSD-American Mineralogist Crystal Structure Database (2020) http://rruff.geo.arizona.edu/AMS/amcsd.php. Assessed 16 December 2020.

Baynes RE, Dedonder K, Kissel L, Mzyk D, Marmulak T, Smith G, Tell L, Gehring R, Davis J, Riviere JE (2016) Health concerns and management of selected veterinary drug residues. Food Chem Toxicol 88:112-122. https://doi.org/10.1016/j.fct.2015.12.020

Bergaya F, Theng BCG, Lagaly G (2006) Handbook of Clay Science. General introduction: Clay, clays minerals and clay science, Elsevier, Amsterdam.

Blanco G, Junza A, Barron D (2017) Occurrence of veterinary pharmaceuticals in golden eagle nestlings: Unnoticed scavenging on livestock carcasses and other potential exposure routes. Sci Total Environ 586:355-361. https://doi.org/10.1016/j.scitotenv.2017.02.023

Camargo OA, Moniz AC, Jorge JA, Valadares JMAS (1986) Métodos de análise química, mineralógica e física de solo do Instituto Agronômico de Campinas. Boletimtécnico 106.

Carrasquillo AJ, Bruland GL, MacKay AA, Vasudevan D (2008) Sorption of ciprofloxacin and oxytetracycline zwitterions to soils and soil minerals: Influence of Compound Structure. Environ Sci Technol 42:7634-7642. https://doi.org/10.1021/es801277y

Carvalho IT, Santos L (2016) Antibiotics in the aquatic environments: A review of the European scenario. Environ Int 94:736-757. https://doi.org/10.1016/j.envint.2016.06.025

Chen H, Ma LQ, Gao B, Gu C (2013) Effects of $\mathrm{Cu}$ and $\mathrm{Ca}$ cations and $\mathrm{Fe} / \mathrm{Al}$ coating on ciprofloxacin sorption onto sand media. J Hazard Mater 15:375-381. https://doi.org/10.1016/j.jhazmat.2013.03.014

Chen Y, Rosazza J, Reese C, Chang HY, Nowakowski M, Kiplinger J (1997) Microbial models of soil metabolism: biotransformations of danofloxacin. J Ind Microbiol Biot 19: 378384. https://doi.org/10.1038/sj.jim.2900409

Conkle JL, Lattao C, White JR, Cook RL (2010) Competitive sorption and desorption behavior for three fluoroquinolone antibiotics in a wastewater treatment wetland soil. Chemosphere 80:1353-1359. https://doi.org/10.1016/j.chemosphere.2010.06.012 
International Journal of Agriculture and Environmental Research

ISSN: 2455-6939

Volume: 07, Issue: 01 "January-February 2021"

Cuprys A, Pulicharla R, Lecka J, Brar SK, Drogui P, Surampalli RY (2018) Ciprofloxacin-metal complexes - stability and toxicity tests in the presence of humic substances. Chemosphere 202:549-559. https://doi.org/10.1016/j.chemosphere.2018.03.117

Dionisio AC, Rath S (2016) Abamectin in soils: Analytical methods, kinetics, sorption and dissipation. Chemosphere 151: 17-29. https://doi.org/10.1016/j.chemosphere.2016.02.058

Doorslaer XV, Dewulf J, Van Langenhove H, Demeestere K, (2014) Fluoroquinolone antibiotics: An emerging class of environmental micropollutants. Sci Total Environ 500501: 250-269. https://doi.org/10.1016/j.scitotenv.2014.08.075

FAI (2019) What constitutes critically important antimicrobials? http://www.faifarms.com/portfolio-item/what-constitutes-critically-importantantimicrobials/. Accessed 16 December 2019.

Figueroa-Diva RA, Vasudevan D, Mackay AA (2010) Trends in soil sorption coefficients within common antimicrobial families. Chemosphere 79:786-793. https://doi.org/10.1016/j.chemosphere.2010.03.017

Figueroa RA, Mackay AA (2005) Sorption of oxytetracycline to iron oxides and iron oxide-rich soils. Environ Sci Technol 39:6664-6671. https://doi.org/10.1021/es0480441

Graouer-Bacart M, Sayen S, Guillon E (2015) Adsorption of enrofloxacin in presence of Zn (II) on a calcareous soil. Ecotoxicol Environ Saf 122:470-476. https://doi.org/10.1016/j.ecoenv.2015.09.019

Gu C, Karthikeyan KG (2005) Interaction of tetracycline with aluminum and iron hydrous oxides. Environ Sci Technol 39:2660-2667. https://doi.org/10.1021/es048603o

Gu X, Tan Y, Tong F, Gu C (2015) Surface complexation modeling of coadsorption of antimicrobial ciprofloxacin and $\mathrm{Cu}$ (II) and onto goethite surfaces. Chem Eng J 269:113120. https://doi.org/10.1016/j.cej.2014.12.114

Ho YS, Mackay G (1998) A comparison of chemisorption kinetic models applied to pollutant removal on various sorbents. Process Saf Environ 76:332-340. https://doi.org/10.1205/095758298529696

ISRIC-International Soil Reference and Information Centre (2002) Procedures for Soil Analysis, sixth ed. ISRIC, The Netherlands. 
International Journal of Agriculture and Environmental Research

ISSN: 2455-6939

Volume: 07, Issue: 01 "January-February 2021"

Jalil MER, Baschini M, Sapag K (2015) Influence of $\mathrm{pH}$ and antibiotic solubility on the removal of ciprofloxacin from aqueous media using montmorillonite. Appl Clay Sci 114:69-76. https://doi.org/10.1016/j.clay.2015.05.010

Jie Z, Zhaojun L, Gaofei G, Wanchun S, Yongchao L, Laossheng W (2009) Impacts of soil organic matter, $\mathrm{pH}$ and exogenous copper on sorption behavior of norfloxacin in three soils. J Environ Sci 21:632-640. https://doi.org/10.1016/S1001-0742(08)62318-9

Kong X, Feng S, Zhang X, Li Y (2014) Effects of bile salts and divalent cations on the adsorption of norfloxacin by agricultural soils. J Environ Sci 26:846- 854. https://doi.org/10.1016/S1001-0742(13)60480-5

Kuppusamy S, Kakarla D, Venkateswarlu K, Megharaj M, Yoon YE, Lee YB (2018) Veterinary antibiotics (VAs) contamination as a global agro-ecological issue: A critical view. AgrEcosyst Environ 257:47-59. https://doi.org/10.1016/j.agee.2018.01.026

Li Z, Hong H, Liao L, Ackley CJ, Schulz, L.A., MacDonald, RA, Mihelich, AL, Emard SM (2011) A mechanistic study of ciprofloxacin removal by kaolinite. Colloid Surface B 88:339-344. https://doi.org/10.1016/j.colsurfb.2011.07.011

Liu Y, Dong C, Wei H, Yuan W, Li K (2015) Adsorption of levofloxacin onto an iron-pillared montmorillonite (clay mineral): Kinetics, equilibrium and mechanism. Appl Clay Sci 118:301-307. https://doi.org/10.1016/j.clay.2015.10.010

Mackay A, Vasudevan D (2012) Polyfunctional ionogenic compound sorption: Challenges and new approaches to advance predictive models. Environ Sci Technol 46:9209-9223. https://doi.org/10.1021/es301036t

Madejová J (2003) FTIR techniques in clay mineral studies. Vib. Spectrosc. 31, 1, 1-10.

Martínez-Mejía MJ, Sato I, Rath S (2017) Sorption mechanism of enrofloxacin on humic acids extracted from Brazilian soils. EnvironSciPollut Res 24:15995-16006. https://doi.org/10.1007/s11356-017-9210-3

Melo VF, Alleoni LRF (2009) Química e mineralogia do solo. Parte I- Conceitos Básicos, primeira ed. Sociedade Brasileira de Ciência do solo, Viçosa.

Nakamoto K (2009) Infraredand Raman SpectraofInorganicandCoordinationcompounds, fourth ed. Wiley-Interscience, New York. 
International Journal of Agriculture and Environmental Research

ISSN: 2455-6939

Volume: 07, Issue: 01 "January-February 2021"

Nowara A, Burhenne J, Spiteller M (1997) Binding of fluoroquinolone carboxylic acid derivatives to clay minerals. J Agric Food Chem 45:1459-1463. https://doi.org/10.1021/JF960215L

OECD-The organization for Economic Co-operation and Development (2000) Test No. 106: Adsorption-desorption using a batch equilibrium method. OECD Publishing.

Pan M, Chu LM (2017) Fate of antibiotics in soil and their uptake by edible crops. Sci Total Environ 599-600:500-512. https://doi.org/10.1016/j.scitotenv.2017.04.214

Peruchi LM, Fostier AH, Rath S (2015) Sorption of norfloxacin in soils: Analytical method, kinetics and Freundlich isotherms. Chemosphere 119:310-317. https://doi.org/10.1016/j.chemosphere.2014.06.008

Pfizer (2018) Finding of no significant impact for ADVOCIN ® 180: Danofloxacin 18\% injectable solution for the treatment of respiratory disease in cattle. Available at https://www.fda.gov/OHRMS/DOCKETS/98fr/141-207-fonsi01.pdf. Accessed 14 March 2018.

Rath S, Fostier AH, Pereira LA, Dionisio AC, Ferreira FO, Doretto KM, Peruchi LM, Vieira A, Neto OFO, Bosco SMD, Martínez-Mejía MJ (2019) Sorption behaviors of antimicrobial and parasitic veterinary drugs on subtropical soils. Chemosphere 214:11-122. https://doi.org/10.1016/j.chemosphere.2018.09.083

Riaz L, Mahmood T, Khalid A, Rashid A, Siddique MBA, Kamal A, Coine MS (2018) Fluoroquinolones (FQ) in the environment: A review on their abundance, sorption and toxicity in soil. 191:704-720. https://doi.org/10.1016/j.chemosphere.2017.10.092

Rivagli E, Pastorello A, Sturini M, Marashi F, Speltini A, Zampori L, Malavasi L, Profumo A (2014) Clay minerals for adsorption of veterinary FQs: Behavior and modeling. J Environ Chem Eng 2:738-744. https://doi.org/10.1016/j.jece.2013.11.017

Russel JD, Wilson MJ (1987) A handbook of determinative methods in clay mineralogy, first ed. Blackie\&SonLimited, pp.133-173.

SINDAN-Sindicato Nacional da Indústria de Produtos para Saúde Animal Compêndio de Produtos Veterinários (2019) https://sistemas.sindan.org.br/cpvs/pesquisar.aspx. Accessed 16 December 2020. 
Stevenson FJ (1994) Humus chemistry: Genesis, composition, reactions, second ed. Wiley \& Sons, New York.

Tan Y, Guo Y, Gu X, Gu C (2015) Effects of metal cations and fulvic acids on the adsorption of ciprofloxacin onto goethite. Environ Sci Pollut Res Int 22: 609-617. https://doi.org/10.1007/s11356-014-3351-4

Teixidó M, Medeiros J, Beltrán J, Prat MD, Granados M (2014) Sorption of enrofloxacin and ciprofloxacin in agricultural soils: Effect of organic matter. Adsorpt Sci Technol 32:153163. https://doi.org/10.1260\%2F0263-6174.32.2-3.153

Vasudevan D, Bruland GL, Torrance BS, Upchurch VG, MacKay AA (2009) Ph-dependent ciprofloxacin sorption to soils: Interaction mechanisms and soil factors influencing sorption. Geoderma 151:68-76.https://doi.org/10.1016/j.geoderma.2009.03.007

Wang M, Li Z, Hong H, Wu Q (2013) Enrofloxacin uptake and retention on different types of clays. J Asian Earth Sci 77:287-294. https://doi.org/10.1016/j.jseaes.2013.02.032

Yan W, Hu S, Jing C (2012) Enrofloxacin sorption on smectite clays: Effects of pH, cations, and humic acid. J Colloid Interf Sci 372:141-147. https://doi.org/10.1016/j.jcis.2012.01.016

Zhao J, Liang G, Zhang X, Cai X, Li R, Xie X, Wang Z (2019) Coating magnetic biochar with humic acid for high efficient removal of fluoroquinolone antibiotics in water. Sci Total Environ 688:1205-1215. https://doi.org/10.1016/j.scitotenv.2019.06.287 